\title{
Strategic Recovery? The Conservatives Under David Cameron
}

\author{
BY JANE GREEN
}

\begin{abstract}
Under David Cameron the Conservative party recovered sufficiently to deliver a Conservative Prime Minister. Cameron achieved what three leaders before him did not: a consistent poll lead over Labour and a broadening of the Conservative message. This chapter also highlights two major limitations to the Conservative 'recovery'; (i) the size of the Conservative base has not enlarged: roughly the same proportion of people identify with the Conservatives as did so in 1997, and voters' feelings towards the Conservative party saw just a small improvement; and (ii) although many evaluations of Conservative competence were less negative by 2010, the ratings were not yet clearly positive. The Conservative lead entering the election was narrow on many key criteria, and the campaign failed to change this position. Furthermore, this article suggests that Conservative ratings became positive in 2008, as the financial crisis occurred, and narrowed as Britain emerged from recession. Although much can be attributed to the selection of a new leader, the Conservative 'recovery' was due to the broader political context, and it was also a partial recovery, at best.
\end{abstract}

IN THE final 36 hours of the 2010 election campaign, as David Cameron made his night and day sprint across the country to win lastminute votes, the Leader of the Opposition must have wondered why he was not walking into a comfortable and sizable victory. The preceding year had seen Conservative vote intentions reach the magic $40 \%$ level-enough to secure a firm majority-and Cameron had long been viewed as the answer to the Conservative party's opposition problems. $\mathrm{He}$ was campaigning against one of the most unpopular Prime Ministers in history, Gordon Brown, who had presided over the worst economic crisis since the Great Depression. This was arguably the Conservatives' best opportunity to form a government in a generation.

David Cameron increased the Conservative party's vote share by just $3.8 \%$ to $36.1 \%$, between 2005 and 2010 . This was only a $4.4 \%$ increase on the $31.7 \%$ share achieved by William Hague in 2001, in a much derided campaign. Winning 307 seats in parliament in 2010, David Cameron failed to reach the number of seats, 326, to obtain an overall majority. He achieved a much larger seat gain than his immediate predecessors, adding 97 Conservative MPs to the House of 
Commons, but instead of celebrating the arrival of an exclusively Conservative government following the first election victory for the party in 31 years, Conservative supporters looked on as their party formed a coalition with the Liberal Democrats—a party seen by many as bitter campaigning rivals.

This article offers an analysis of the Conservative party's successes, and failures, which precipitated the result on 7 May 2010. It traces the journey of David Cameron's Conservatives in opposition, highlighting the mixed picture of success achieved in the first two years, and then the latter three years of his opposition leadership. It offers two main observations to consider the electoral achievements, or otherwise, of Cameron's Conservative party in opposition. (i) David Cameron increased the potential vote for the Conservative party but he did not enlarge the Conservative base. Roughly the same number of people expressed an affiliation for the Conservatives in 2010 as they did following the disastrous ERM crisis for the Conservatives in 1993. The number of voters on which David Cameron could count upon to vote Conservative in 2010 was not significantly larger than the number available to William Hague, Iain Duncan-Smith or Michael Howard. (ii) David Cameron's Conservative party was no longer viewed negatively, but neither was it viewed positively. The oft-cited strategy of decontaminating the Conservative brand had succeeded, to an extent, but the next step-of securing positive ratings on ideology, competence and leader qualities-had not been achieved. For voters undecided about their vote choice-of which there were many ${ }^{1}$ - the 'utility differential' between the main political parties, failed to weigh strongly in the Conservatives' favour.

By the time of the 2010 campaign, many voters wanted a change, but could not yet put their faith in a government run by the Conservatives. The party needed a strong campaign to persuade potential voters, but in the event the campaign was a sideshow to the firstever leadership debates, which derailed the Conservative strategy. These were all among the reasons that David Cameron stood holding a halibut at 6 a.m. on the eve of polling day in Grimsby, on the campaign trail in his last-dash to win a Conservative majority, but ultimately also the reasons why he was standing outside Downing Street on the morning of Tuesday 11 May 2010 with his Deputy Prime Minister, Nick Clegg, the leader of the Liberal Democrat party.

\section{David Cameron: chosen one}

All political parties learn lessons from defeat. The lesson the Conservative party learned from the general elections of 1997, 2001 and 2005, was that no matter how hard they tried, the electorate-and the media-would not give the party a fighting chance until its image had significantly improved. The now well-known observation-that voters rejected policies they would otherwise support when they were 
informed they were Conservative policies-motivated the strategy. This phenomenon, known simply as 'bias' (or the reverse effect, assimilation), reflects the endogenous nature of party evaluations and policy attitudes. $^{2}$ After eight years in opposition, by 2005, insufficient numbers of voters viewed the Conservative party as an acceptable selfidentifying label. The party had failed to win back the large sections of support it lost in the 1992-1997 period-those voters who viewed the party as 'good for one class', but not 'good for all'.

The negative image the Conservative party carried would not change, it was argued, so long as the party elected the same kind of leader and campaigned on the same kinds of issues-those issues which, ironically, the party was most trusted and most highly rated. The Conservative party needed a leader who could pull the image of the Conservative party into the centre ground, even if this centrist shift entailed relatively little policy change, and who would compel voters to adjust their perceptions of the Conservative party. In effect, David Cameron was to be the Conservatives' Clause IV moment-the symbolic change which signalled a new version of Conservatism. ${ }^{4}$

This was not a lesson the Conservative party learned particularly quickly or unanimously. The election contest of 2005, following the resignation of its leader Michael Howard, saw four candidates enter the race: Kenneth Clarke, Liam Fox, David Davis and David Cameron. ${ }^{5}$ Two could be viewed broadly as coming from the right of the party, Liam Fox and David Davis, and two from the centre, Kenneth Clarke and David Cameron. However, the right and centre of the contemporary Conservative party, and its salient defining features, could quite easily be misunderstood.

In the midst of strategic difficulties there was a genuine split within the Conservative parliamentary party about the strategy the Conservative party should adopt, as well as, of course, individual differences in priorities and agendas. Few now argued that the Conservatives should simply wait for an economic downturn and for the issues of Europe, immigration and crime to come to the fore (those issues on which the Conservatives were most trusted). There was, however, a dilemma, characterised by whether parties win elections by giving emphasis to their core strengths on which they have a longstanding reputation-in this case taking a decentralising, family focused, tough on crime, pro-business, anti-immigration approach and maintaining a socially conservative commitment-or whether the Conservative party should simply move with the times, embracing social liberalism, rejecting some of its past, and actively avoid Conservative strengths to focus predominantly on issues traditionally 'owned' ${ }^{6}$ by Labour; the NHS being the defining issue, and to a lesser extent an issue not owned by any party-the environment. The first strategy embraced the existing strengths of the party, believing that voters would come back to the Conservatives when they were 
disillusioned with Labour, with some broadening out in tone and emphasis. The second strategy was premised on the view that only by avoiding all issues on which Conservatives were usually associated, and by taking a strategy which challenged people's views of modern Conservatism-rather than confirming them-would voters believe that the Conservative party had changed. In this context the Conservative party held its leadership contest.

Kenneth Clarke, a known Europhile, promised experience and popularity. He did not define himself by the electoral strategy he would employ, but was by far the most popular leadership candidate in opinion polls-a fact the Conservative party could not easily ignore. However, with keen memories of splits on Europe, and a euro-sceptic party, the argument that Clarke would divide the party tapped into a real concern, and Clarke was not helped by a reportedly 'lazy campaign'. These negatives left Clarke in fourth and last place in the first ballot on 18 October 2005 among Conservative MPs. Clarke received 38 votes, Fox 52, Davis 62 and Cameron 56.

Liam Fox and David Davis were both ostensibly candidates from the right. Liam Fox campaigned on the 'broken society', providing the right of the party with popular themes on marriage and the family, as well as on welfare, but also reassuring more centrist Conservatives that his focus would be on the poorest in society-rather than a traditional Conservative constituency. However, this strategy echoed the much misunderstood strategy of Iain Duncan-Smith, a feature which may have plausibly contributed to Dr Fox's unsuccessful ballot at the second round. He came third with 51 votes, to David Davis' 57 and David Cameron's 90; a result which took Davis and Cameron to the membership ballot.

David Davis was, then, the favourite candidate of the right and Cameron the candidate of the centre. Davis had been the frontrunner from the outset and had come first in the first parliamentary party ballot. He brought together experience with a straight talking electoral appeal, and emphasised the need for the Conservative party to 'maintain its traditional values'-a clear signal that his leadership would not entail a radical shift in style or emphasis. However, he had a reputation as a bully and stories circulated about an abrupt potential leadership style. Furthermore, when both candidates gave speeches at the party conference in September 2005, Davis' was lacklustre, lacking impact.

In the absence of Ken Clarke, David Cameron could command the support of the centre. This was a slightly surprising scenario. Cameron himself had not been a quintessential moderniser. He was an advisor to the John Major government, he had written the manifesto campaigned upon by Michael Howard, and was the preferred candidate of Howard during the leadership race. Cameron was also Eton and Oxbridge educated. In fact, he was to become the first Conservative leader in 40 years to come from a non-state education background. $\mathrm{He}$ 
was by far the least experienced. An MP for only four years, Cameron's leadership campaign had seemed unlikely, but his own leadership bid speech ('the one without notes') at Conservative party conference propelled him to pole position. Cameron distanced his strategy from those tried before and argued for a change and modernisation in the party's 'culture, attitudes and identity'. ${ }^{7}$ Although he promised little in the way of specific policy change, he argued for a change in the relevance of the message, and a broader and less negatively toned response to the Labour government. This was to be the strategy pursued in the following years.

The two final candidates were polled in a postal ballot of all eligible Conservative members. Cameron beat David Davis by 134,446 votes to 64,398-a convincing victory, and he became leader of the Conservative party on 6 December 2005. This party, whose membership is traditionally composed of predominantly older voters, women, rural and suburban middle and upper middle class voters, ${ }^{8}$ chose a leader who challenged the party's emphasis, moved the party onto the issue of the NHS, and diminished the party's focus on immigration and Europe. This was a vote-seeking and office-seeking grassroots party, eager for power.

\section{A strategy for change}

David Cameron benefited from a new electoral context: one in which the Labour party, and Tony Blair in particular, had lost credibility and trust over its action in Iraq, ${ }^{9}$ and where the Labour party in government was beset by increasing unpopularity. William Hague, Iain Duncan-Smith and Michael Howard had all led the Conservative party when the Labour party was mostly significantly ahead in the polls. Despite various strategic efforts, and a plea for patience among colleagues, the leadership periods for Hague and Duncan-Smith were characterised by persistent dissent over strategy (whereas Howard organised the party effectively for the 2005 election). No matter what these earlier leaders did, it appeared to make no impact upon the electorate and ultimately saw no consistent and sizable improvement in the polls.

On 24 June 2007 Gordon Brown was crowned Labour party leader, and although he enjoyed an early period of popularity, his honeymoon period was short-lived. Not only were Labour's vote intention leads reduced by 2008 , but so were Labour's ratings on the valence issues dominating the concerns of the electorate, such as public services and most damagingly, the economy. A new issue agenda was emerging based on security and immigration, on which Labour did not have a lead. ${ }^{10}$ As long as the Conservatives were gaining in the polls, and Labour's issue advantages were narrowing, David Cameron could sustain support for a strategy of focusing on a new and broad issue 
agenda, in place of a narrower focus on issues of Conservative strength.

It would be incorrect, however, to describe the period as an overnight success. During the first two years of Cameron's leadership, the Conservatives did not look set to win the 2010 election, and the period was also characterised by questions over strategy, similar to those raised for leaders before him. Between December 2005 and December 2007, the Conservative poll rating was in the low thirties (an average $33.3 \%$ in this period). The Labour party maintained a consistent lead, and remained so until the autumn of 2008.

There was an early test of David Cameron's leadership, and strategy, in the Bromley and Chislehurst by-election, in June 2006. This by-election should have been a safe Conservative hold, a Conservative seat with a majority of 13,342 held by the late Eric Forth. The Conservative candidate Bob Neill won the seat with a majority of just 633 , losing $11.1 \%$ in vote share compared with the 2005 election. This was a shock to the parliamentary party, as the first electoral test of the new leader who was supposed to deliver an electoral recovery. Cameron's popularity enabled him to quell these questions and he benefited from one key fact: there was no other potential leader to replace him. Any Conservatives disenchanted with Project Cameron knew they had, for the moment, little alternative.

The next high-profile test came in the form of European elections in 2009. The Conservatives 'won' these elections, gaining most seats and votes, but the party in second place was the UK Independence Party (UKIP). Although a disaster for Labour, such a surge in euro-sceptic support signalled the possibility that euro-sceptic voters were sufficiently numerous and willing to support UKIP over the Conservatives. It was the European elections, and the perceived success of the Conservative euro-sceptic campaign in 1999 which was argued to have pulled Hague onto a disproportionately euro focused general election campaign in 2001. ${ }^{11}$ Cameron made no such reaction in focus, continuing to downplay the 'Europe issue' in the months and years ahead.

Cameron pushed ahead with a series of symbolic gestures, some which angered MPs in his party but all designed to signal 'change'. The four most noticeable were his policies on ruling out the revival of grammar schools, via a speech made by David Willetts; the commitment to environmentalism, which included opposition to a third runway at Heathrow; the claim to be the 'party of the NHS' and to downplay traditional Conservative issues, most strikingly the issue of immigration; and his European policy and decision to remove the Conservatives from the European People's Party (EPP). ${ }^{12}$

These initiatives saw mixed success. The first was seen as an opportunity to pick a fight with the party, with Cameron describing the resulting opposition to the policy as 'ideological self-indulgence'. ${ }^{13}$ The policy changed to considering grammar schools where a pressing need 
existed, and the internal dissent, signalling a process of confrontation, may also have contributed to the view that the Conservative party (rather than its leadership) was still the same. The new focus on green issues was an affront to some of those who viewed the party as on the side of business. It is still a position on which many Conservative MPs remain unconvinced. Cameron's focus on the environment, reviving Hague's slogan 'Vote Blue, Go Green', was a clear attempt to focus on an issue seen as the preserve of the left, and was matched by the new Conservative tree logo-a statement of change. Cameron's focus on the NHS was the cause long argued for by arch Conservative modernisers, although by 2010, when Cameron announced the party's policies, Labour's rating on the issue, and its salience, had both descended. Cameron committed to increase spending on the NHS. He consistently refused to give prominence to the issue of immigration-an issue of clear Conservative strength, one on which both Hague and Howard had campaigned before him. His different issue agenda and more conciliatory tone were the clearest strategic differences in comparison to his predecessors. On one issue, Cameron moved to the right, although his euro-scepticism was matched by his party and to some degree, by the country, given a majority euro-sceptic position. Cameron's withdrawal of Conservative MEPs from the EPP (the centre-right grouping in Europe) led to his party's European representatives forming part of a new grouping of euro-sceptic European Conservatives. Although ideologically and institutionally significant, Cameron avoided focusing on the issue in his speeches or in his campaigns. The Conservative party moved to a more moderate centre on domestic policy, doing so in emphasis, if not obviously in position, but shifted ostensibly towards a more euro-sceptic institutional position.

The end result, it seemed, was some confusion. On policy, few voters seemed to understand what the Conservatives stood for. The change in emphasis and tone had not been matched by the unveiling of a clear philosophy, and many of the party's policies had been kept under wraps. Some policies, such as the 'Free Schools' policy, were better researched versions of existing ideas, but the Conservatives feared they would lose policies to Labour if they announced them too soon. Despite a new leader, a new logo, considerable attempts to select more women and minority candidates, an internal refocus onto social justice and the pursuit of a different issue agenda, many voters had not noticed much change. A survey for Politics Home, in October 2009 (during party conference) revealed that almost half of respondents thought the party had not 'changed significantly' and those who thought the party had changed were mostly prior Conservatives. ${ }^{14}$

\section{Winning some minds but few hearts}

In autumn 2007 Northern Rock announced its approach to the Bank of England for assistance and the financial crisis hit the UK. Opinion polls 
showed an initial Labour peak in the late summer of 2007, following the ascent of Gordon Brown, but more negative ratings by early 2008, after Brown eschewed an early election and when the force of the financial crisis had begun to hit home. From thereon the Conservative lead over the Labour party was almost constant. Between September 2008 and May 2010 the average Conservative vote intention was 36.5\%, just above the $36.1 \%$ the party achieved in the May 6 general election poll. These poll leads were matched by more positive Conservative ratings on a range of policy issues, and emerging support for David Cameron as leader (see below). There appeared to be a direct and an indirect effect of the economic crisis on Labour's popularity, in favour of the Conservatives. The direct effect was a loss of Labour's opinion poll lead, almost immediately following the onset of the credit crunch. The indirect effect was a loss of general performance ratings on Labour leadership and on a range of issues-all of which gave the Conservatives a slight relative advantage. If voters turned towards the Conservatives, they appeared to do so as a judgment on the government. This does not equate, however, to a 'revival' attributable to the Cameron strategy, or a recovery in the popular support for the British Conservative party.

An alternative way of evaluating the relative success of the 20052010 years is to examine the 'normal vote' ${ }^{15}$ of the party, alternatively defined as those voters who were willing to express a party identification. ${ }^{16}$ Although party identification is used by some as a 'running tally ${ }^{17}$ of party performance and competence, the concept is used by others to define the expressive attachments held by voters for a party. ${ }^{18}$ David Cameron stated a hope, in his 2005 leadership bid speech at the Conservative party conference: 'I want people to feel good about being a Conservative again'. It is possible that voters judging the Labour party responsible for the economy were willing to lend their support to the Conservatives, without an improvement in the size and popular support for the Conservatives in the form of 'feeling good' or expressing an identification. It was this identification support that was lost so dramatically between 1992 and $1997 .{ }^{19}$ As either a running tally or an expressive identity, the proportion of people willing to identify with a party is a signal of that party's reliable vote.

Figure 1 ( $\mathrm{a}$ and $\mathrm{b}$ ) below suggests that on this criterion of support the Conservative party had not succeeded. Note that the time axis varies in the graphs, to provide a comparison of early British Election Study observations in the 1970s through 2000s, and the monthly Continuing Monitoring Survey (CMS) data between June 2008 and April 2010. The figures reveal that the Conservative party retained approximately the same proportion of 'identifiers' as it achieved in 1997 and never recovered to 1992 levels. Whereas vote intention increased under David Cameron, the proportion of identifiers with the party resembled the flat lining the party had been experiencing, but for vote intention, under Hague, Iain Duncan-Smith and Howard. ${ }^{20}$ 
Furthermore, comparing these patterns with those for the Labour party [Figure 2 ( $\mathrm{a}$ and $\mathrm{b})$, below], the Conservative recovery can be questioned further still. Notwithstanding a period of partisan dealignment, ${ }^{21}$ in which we might evaluate a stable degree of partisanship as something of a success, the Labour party retained its 'base' support, in the form of those people still willing to express identification with Labour, despite significant setbacks. The Conservatives, meanwhile, failed to increase the size of the Conservative base over an 18 year period.

Figures $1(\mathrm{a}$ and $\mathrm{b})$ and $2(\mathrm{a}$ and $\mathrm{b})$ together suggest that there has been a decoupling of vote intention and party identification in the

Figure 1. (a) Conservative party identification and vote, 1974-2005 (BES data). (b) Conservative party identification and vote intention, July 2008-April 2010 (BES CMS data).

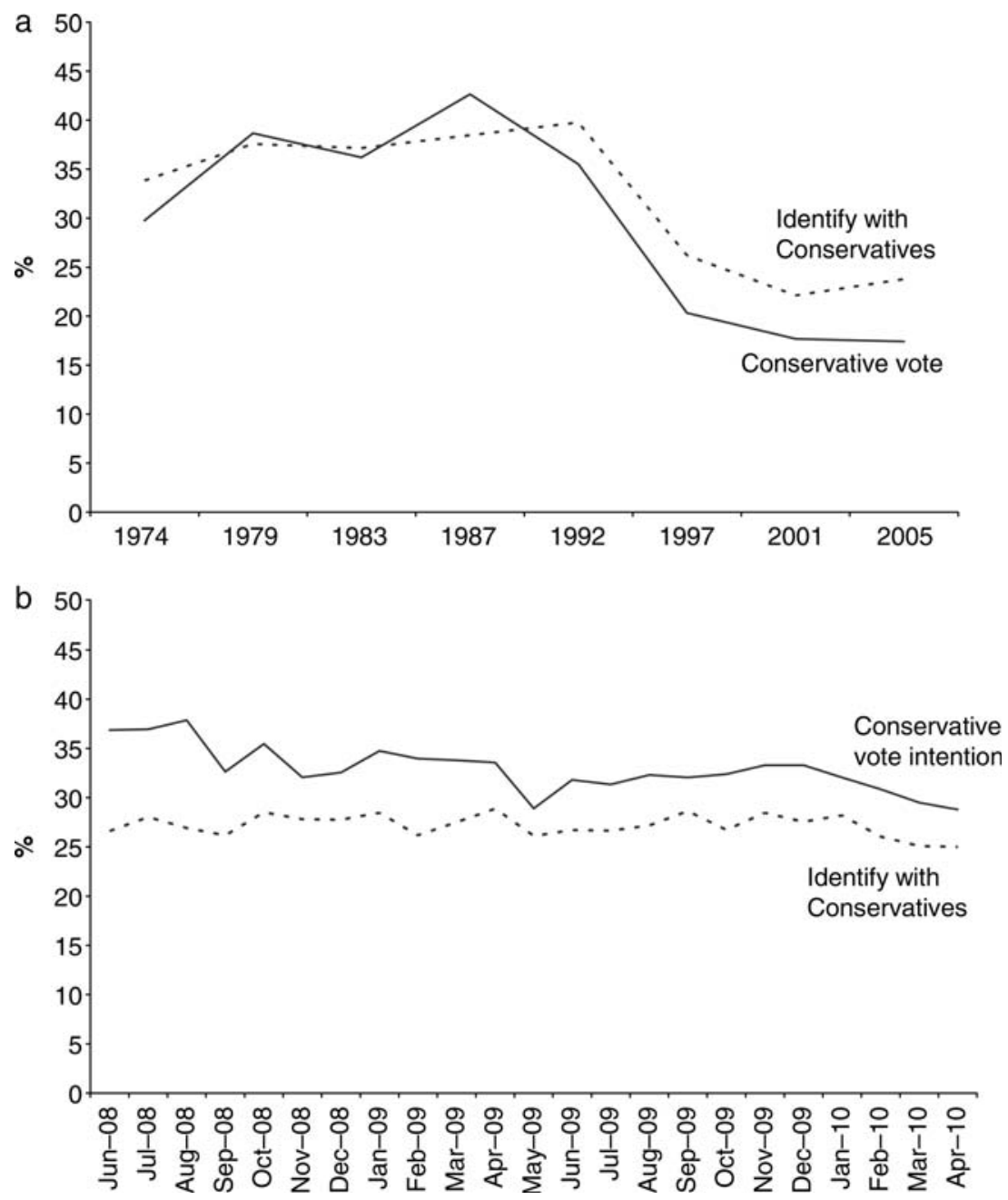


Figure 2. (a) Labour party identification and vote, 1974-2005 (BES data). (b) Labour party identification and vote intention, July 2008-April 2010 (BES CMS data).
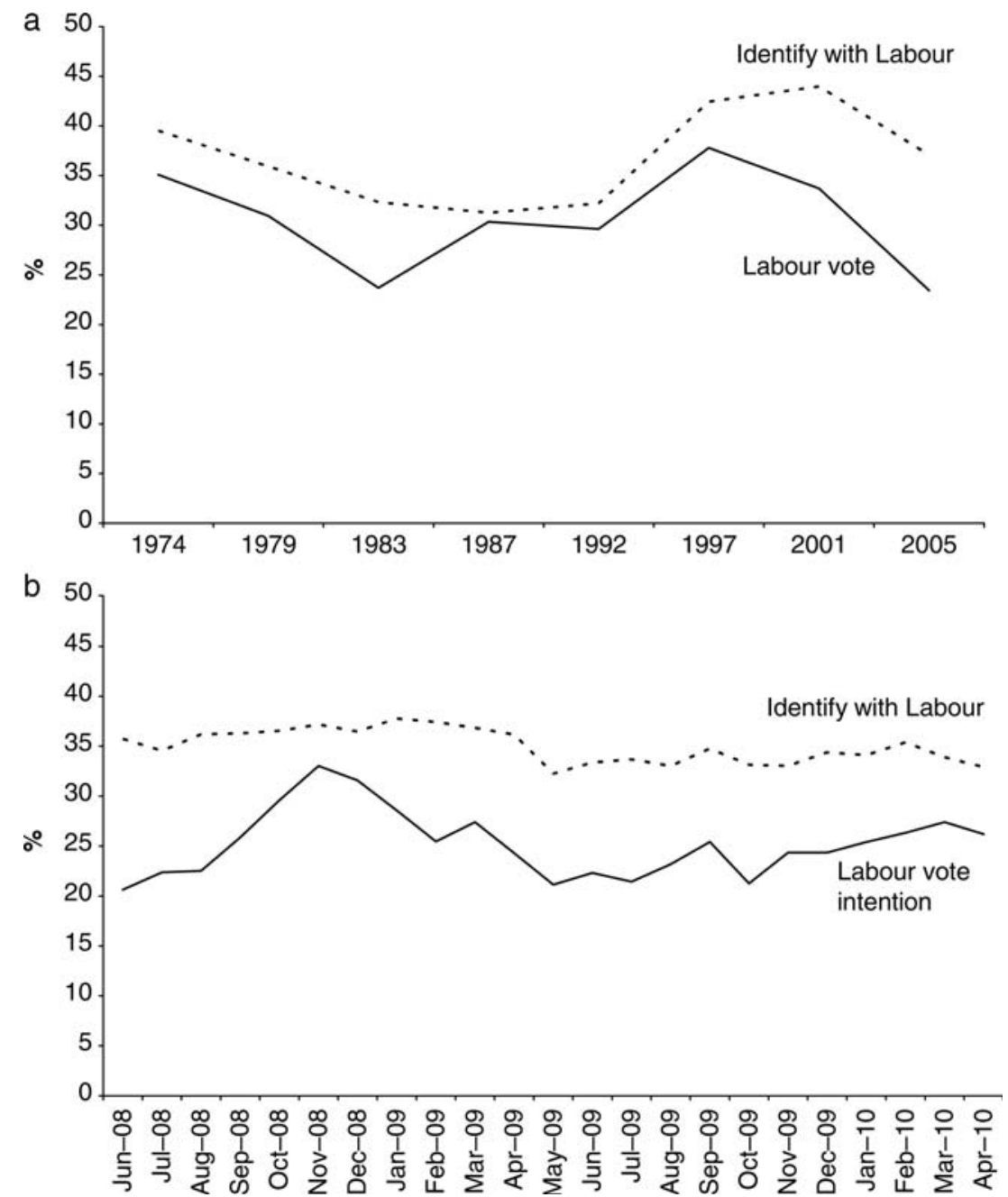

British electorate. Whereas party identification and vote intention have corresponded closely in Britain in the past, calling into question the application of the expressive concept of party identification in the British electorate, ${ }^{22}$ Labour party identification has proved relatively robust to its declining popularity in vote intention over recent years. Conversely, whereas new voters became available to the Conservative party under David Cameron, these voters did not all view themselves as Conservatives. The Conservative party had succeeded in persuading new (or returning) voters to lend the party their support, but had not succeeded in making more voters 'feel good about being a 
Conservative'-to the point of expressing a self-identification with the Conservatives.

An additional way of evaluating the strength of feeling towards Cameron's Conservatives, positive or negative, is via a comparison of thermometer scores in British Election Studies. These thermometer scales ask respondents to rate their feelings towards each main party, from 0 (strongly dislike) to 10 (strongly like). The table below provides the average score for the three main parties in the 2001 post-election BES, the 2005 pre-election BES and the 2010 pre-election BES. ${ }^{23}$ Given the furore over MPs expenses, and distrust for politicians, it is relevant to compare these scores by party, since all may have become more unpopular. As the table shows, this was only partially the case (Table 1 ).

The strategy of broadening out the Conservative message, of adopting a less partisan tone, and modernising the party under a new leader did appear to shift voters' liking of the Conservative party to some degree. Prior to the 2010 campaign the Conservatives were the least disliked party. However, although the Conservative party was slightly more liked than it was in 2005, the jump from 2001 to 2005 was larger, and the 2010 ratings were not close to those of the Labour party under Tony Blair. Furthermore, the party was only slightly more liked than Labour under Gordon Brown and Nick Clegg's Liberal Democrats. These incremental improvements may have been due to the broader context. It would not be surprising if the expenses scandal damaged all parties' likeability (and failing to improve the ratings of the Liberal Democrats). On these expressive criteria of support, however, the Conservative strategy made limited progress. Under Cameron's leadership, identification with, and warmth towards, the Conservative party did not significantly increase. In the battle for hearts and minds, the Conservatives had won over some conditional support from some voters but had not yet convincingly won over their hearts.

\section{Neutralising the negative, but not achieving the positive}

The Conservative party achieved improvement on a range of 'valence' criteria-related to performance or competence. The Conservatives were no longer the least popular party in terms of leader approval, they no longer had overwhelmingly negative ratings on important valence issues such as health and education, and crucially, they were, at times, considered the best party on the economy. However, as

1. Feelings towards the main parties: thermometer averages, 2001-2010 (British Election Study 2001, 2005 and 2010 election surveys; 0 strongly dislike; 10 strongly like)

Conservative

2005

2010
3.6

4.4

4.9
Labour

5.7

5.0

4.6
Liberal Democrat

5.0

4.7

4.7 
shown here, the Conservative party no longer had negative ratings but neither were its ratings strongly positive. The party, under Cameron, had succeeded in neutralising the negatives, but had not received a positive lead in a range of important respects. The result was that both main parties entered the election almost neck and neck on many competence judgments, despite Gordon Brown's unpopularity and despite the financial crisis and recession.

David Cameron's leader ratings were more positive than his predecessors'. Cowley and Green ${ }^{24}$ showed the net satisfactiondissatisfaction scores collated by Ipsos-MORI for William Hague, Iain Duncan-Smith and Michael Howard. For all three Conservative leaders, the net ratings showed far more dissatisfaction than satisfaction, albeit after a brief honeymoon period at the beginning of their leaderships. The ratings for Howard were similar to those for Iain Duncan-Smith. Evans and Andersen ${ }^{25}$ argued that William Hague's ratings were strongly determined by those of the party (rather then vice versa), and for eight years it seemed that it was impossible to be a popular leader of such an unpopular party. As the figure below shows, David Cameron managed, for the most part, to buck this trend, although this was not evident towards the early part of his leadership. His relative popularity coincided with the mid-2008 period when Britain experienced the onset of the financial crisis and Gordon Brown's honeymoon period ended.

Figure 3 shows how David Cameron's leadership began with a similar honeymoon to those of his predecessors, and then his netpositive rating (satisfaction-dissatisfaction) declined, reaching its lowest point when Gordon Brown became Labour leader. However, from early 2008 those ratings remained net-positive throughout and even saw peaks of considerable popularity. On this net satisfaction criterion alone, we can surmise that David Cameron became a more popular electoral choice than Conservative leaders before him. Nevertheless, as the Conservatives neared the election, the positive ratings for Cameron only just outweighed the negatives. The gap between the same score for Gordon Brown and the score for David Cameron began to narrow, ${ }^{26}$ although Gordon Brown was still much more disliked than liked. On this basis, David Cameron had an advantage over Gordon Brown, but his satisfaction ratings were not sufficiently high to induce confidence that his leadership alone would deliver an overall majority for the Conservatives.

In addition to the importance of leader ratings, Clarke et al. ${ }^{27}$ point to the importance of party ratings on the most important problem; a measure of trust and competence to deliver on the issues of concern to voters. As discussed earlier, the concept of competence or of 'ownership ${ }^{28}$ was central to the strategic dilemma defining the difficulties of the Conservatives in opposition. The party had been most trusted on issues commonly associated with 'the right': immigration, taxation, 
Figure 3. Net satisfaction-dissatisfaction for Conservative opposition leaders, 1997-2010 (Ipsos-MORI data).

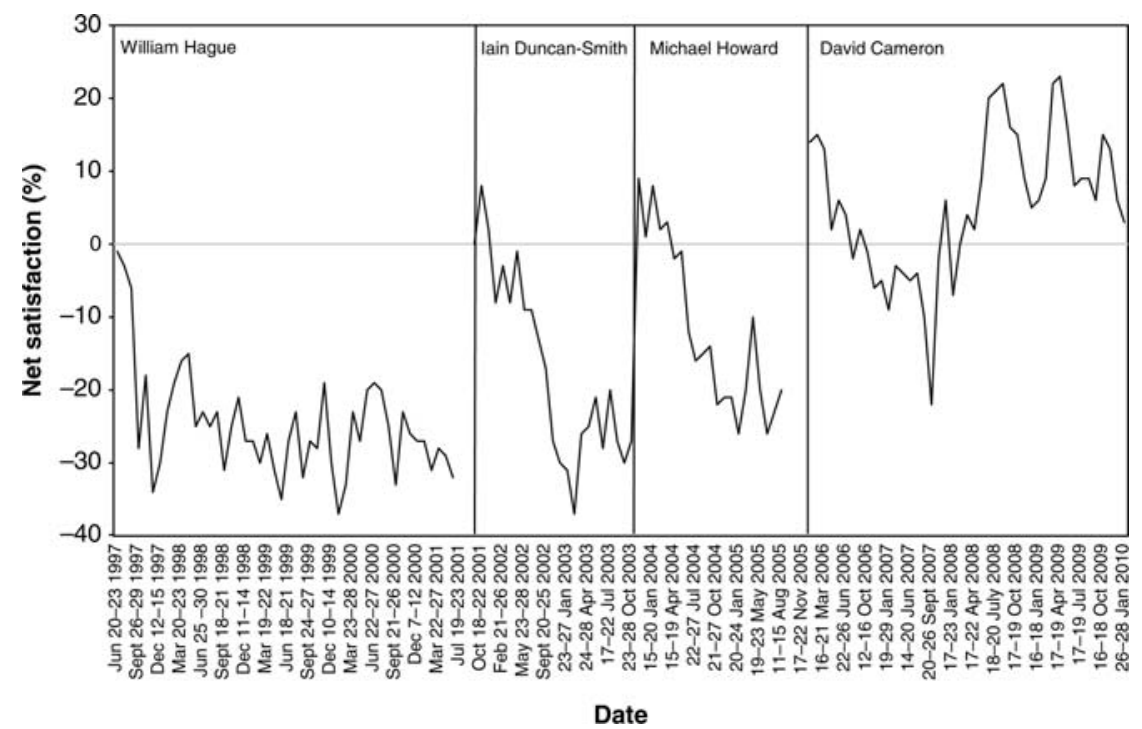

crime and euro-scepticism, but Labour had commanded much higher ratings on issues most important to voters: health, education and the economy. ${ }^{29}$ As ratings of Labour's competence and trust began to decline, so did its relative advantage across the issue domain and David Cameron had a wider pallet of available issues. Cameron also sought to increase his own advantage on 'new' issues (health, the environment) by focusing on these, demonstrating commitment where unable to display handling in office.

The following table demonstrates the improvement made in 'best party on the most important problem', between 2001 and 2010 for the Conservatives on this important valence indicator. This summary measure does not distinguish by issue, and so relates to the overall rating of the party by respondents choosing different issues as their number one concern.

In Table 2 we see, once again, Conservative ratings were only just ahead prior to the 2010 election, comparing the Conservative lead with Labour, and the party failed to gain the proportions held by Labour in 2001 and $2005 .^{30}$ There is no doubting that a jump from 15 to $22.6 \%$ for the Conservatives is significant between 2001 and 2010, but $22.6 \%$ is a low value compared with Labour's ratings in 2001 and 2005. The highest proportion of respondents listed 'no party' or a 'do not know' response prior to the election in 2010, and this climbed as Labour lost its advantage on this measure, rather than translating directly to the Conservatives. 
2. 'Best party on the most important problem' 2001-2010 (\%) (British Election Study, 2001 post-election, 2005-election post and 2010 pre-election)

$\begin{array}{lccc} & 2001 & 2005 & 2010 \\ \text { Conservative } & 15.0 & 20.1 & 22.6 \\ \text { Labour } & 38.5 & 35.8 & 21.2 \\ \text { Liberal Democrat } & 7.6 & 7.4 & 4.6 \\ \text { Other } & 3.5 & 4.9 & 5.3 \\ \text { None/do not know } & 26.8 & 31.8 & 46.2 \\ \text { Total }(n) & 2480 & 3980 & 1882\end{array}$

Under David Cameron, the numbers of issues which could be argued to be off limits in the saliency theory of Budge and Farlie ${ }^{31}$ - those issues which, if campaigned upon, could only hand an advantage to an opponent-were significantly reduced. On all issues, the Labour advantage over the Conservatives had declined by 2010, and on most issues the Conservatives had a narrow lead, ${ }^{32}$ including on the symbolic issue of the NHS. It is not clear whether the new issue handling advantage arose from a strategic emphasis on some issues over others, although this may be a contributing factor. It is much more likely that a general competence advantage-due to the declining popularity of the Labour government and some satisfaction with David Cameron-contributed to more positive ratings on all issues. What is clear was that by 2010, the advantages were not large, as indicated in Table 2. On the criterion of valence issues, we see that although the party's negative ratings had been neutralised, the party did not receive a positive endorsement of its potential handling of the issue agenda. On the issue where the Conservatives had a commanding advantage-immigration-the decision was taken not to place this issue in the long or the short campaign. ${ }^{33}$

Finally and crucially, the pattern also extended to the economy. It was highlighted above that the Conservatives' and David Cameron's fortunes improved when the financial crisis hit Britain in force, in the spring and summer of 2008. However, there was not a simple translation from concerns over the Labour government's handling of the country's finances and, by the time of the general election, the size of the deficit, towards trust in the Conservative government to solve the country's economic problems. Britain emerged from the recession in January 2010, and it was undoubtedly Gordon Brown's best hope that this would help shore up Labour's support. By February 2010 the British Election Study's Continuing Monitoring Survey (CMS) recorded a series of pre-election economic judgements. True, respondents had experienced financial losses $(57 \%$ believed the national economy had got worse in the past year, and $45 \%$ said their own financial situation had worsened), but only $27 \%$ listed Gordon Brown as responsible and $40 \%$ the British government. There was also some anticipation that things would get better or at least not get worse. Sixty-two per cent 
thought their personal circumstances would improve or remain the same and $65 \%$ thought the country's economic situation would get better. The upshot of this was that with many voters believing things might improve, they were now undecided about who to trust. Thirty-one per cent thought that Labour had handled the crisis very or fairly well-a low figure, but only $24 \%$ thought this would be true for the Conservatives. As the election neared, a fascinating trend emerged, which is revealed in the following table of CMS responses to the 'which party is best on the economy' question, monthly during the year (May 2009-April 2010) prior to the 2010 general election.

Table 3 shows that the Conservative lead over Labour on this criterion narrowed as the parties neared the general election, and it did so as Britain emerged from the recession. Strikingly, in the April 2010, as Gordon Brown called the general election, Labour had even gained a lead over the Conservatives on this policy area.

Although the Conservative party had managed to undo a serious disadvantage on economic ratings - an evaluation which had beset the party from the ERM crisis in 1992, and although the Conservatives had gained a lead on the economy in the midst of the recession, the incumbent Labour party went into the election with a narrow advantage over its main opponent, despite presiding over the most serious recession since the Great Depression.

The pre-campaign position of the Conservative party, relative to its opponents, was on a knife-edge. The party had been in opposition for 13 years, and had seen its potential vote reach figures which would assure the party a majority, but as the election neared, the party's ratings on a wide array of measures were not much better than Labour's. It is little wonder that large numbers of voters could not make up their minds prior to Election Day. In theories of party choice, voters are expected to maximise their utilities - the things they want-by choosing the party closest to their preferences. ${ }^{34}$ This utility decision can be

3. 'Best party on the economy' May 2009-April 2010 (\%) (BES Continuous Monitoring Survey)

$\begin{array}{lccc} & \text { Conservatives } & \text { Labour } & \text { Conservative lead } \\ \text { May-2009 } & 34.0 & 24.4 & 9.6 \\ \text { June-2009 } & 34.1 & 26.7 & 7.4 \\ \text { July-2009 } & 35.5 & 25.4 & 10.2 \\ \text { August-2009 } & 35.6 & 25.9 & 9.7 \\ \text { September-2009 } & 34.7 & 29.6 & 5.0 \\ \text { October-2009 } & 36.2 & 26.7 & 9.5 \\ \text { November-2009 } & 34.5 & 27.8 & 6.7 \\ \text { December-2009 } & 33.5 & 29.4 & 4.2 \\ \text { January-2010 } & 36.7 & 29.3 & 7.3 \\ \text { February-2010 } & 34.4 & 31.7 & 2.7 \\ \text { March-2010 } & 34.3 & 32.0 & 2.3 \\ \text { April-2010 } & 34.7 & 35.9 & -1.2\end{array}$


extended to the party who will best deliver or which is most competent, especially when parties offer voters similar policies. ${ }^{35}$ If there is little to differentiate the choices on offer, voters will be indifferent between candidates or parties - a factor which is known to reduce turnout ${ }^{36}$ and which may prompt voters to look to minor or third parties. In 2010, the utility differential between Labour and the Conservatives was small. The Conservatives had a more popular leader than Labour, but the lead had narrowed (and Nick Clegg was slightly preferred to Cameron). There was a tiny gap between the best party on the economy and there was an equally small gap between the best party on the most important issue (which could, of course be the economy for many). The Conservative party was not much more liked than its rivals, and its committed base was no larger than before. In policy terms, voters may have been closer to the Conservatives on some salient issues, but ideologically there was little to distinguish the three main parties from each other, ${ }^{37}$ particularly once Cameron had emphasised his position at the centre. Overall, by the time of the 2010 campaign, voters might have been largely indifferent or at least confused between choices. If the outcome of the general election showed no party with a clear majority, neither did either of the main parties have a clear and overwhelming lead on any criteria entering the election campaign. If either major contender was to make a break though, this needed to happen in the final four weeks of the election, during the short campaign.

\section{Campaign strategy: what strategy?}

David Cameron must have hoped to enter the 2010 general election campaign with a much more convincing set of strengths. However, it was still, in effect, his election to lose. This was a campaign which could, despite electoral bias, have secured a Conservative majority, albeit on a significant swing. It could also have secured a sufficient number of seats to make a minority Conservative government a much more plausible outcome than the result eventually achieved.

The campaign was a series of reactions, for two reasons. First, the Conservatives' main message had not been tested prior to its unveiling, and was quickly dropped once it became clear it was not working. Second, this was a campaign almost completely derailed by Nick Clegg's performance in the first of three leader debates. For these reasons the strategy is difficult to detect. The usual agenda-shaping nature of the campaign had changed in 2010. In previous elections, each party held a daily morning media briefing, and the campaign plan followed an issue-by-issue strategy designed to shape the agenda onto the issues the party wanted to focus upon each day. In 2010, the Conservative and Labour parties ditched these events in favour of schedules on media campaign buses and daily moving briefings. It is not clear whether this meant the parties relinquished control, but it is 
certainly true that their strategies appeared more fluid, reactive and much more difficult to discern.

It is an irony that the criticism made of two of the most derided political campaigns of the last 30 years-the election campaign run by William Hague in 2001 and the campaign run by Michael Foot in 1983 - that opinion polls were not conducted, or rejected, was strangely true for the central platform of the Conservative campaign in 2010: the 'Big Society'. The 'Big Society' was intended to offer an inspirational call to participation and responsibility, to address (perhaps) the taint that there was 'no such thing as society', ${ }^{38}$ and to contrast the Big Society with small government-a philosophy of decentralisation and lower taxation and of the cooperation of voluntary organisations and individuals in addressing 'the broken society'. The theme was given prominence at the start of the campaign, centrestage at the launch of the manifesto. This manifesto was fronted with the words: 'Invitation to Join the Government of Britain' and the prelaunch teaser featured an image on Battersea Power Station, asking 'Who is the New Member of Cameron's Team?' with the answer being 'you'. The Conservatives hoped to inspire a sense of responsibility, of 'togetherness' and a defining philosophy which people could understand, providing a dividing line between the Conservative party and other parties. The result was confusion. This was a party offering a new governing philosophy five years after the previous election and with four weeks until polling day. It sounded ambitious, slightly strange and rather unrealistic. David Cameron attempted to define the agenda in his first leader debate. From that day the campaign theme which was to inspire the country to a Conservative majority was dropped quietly and quickly.

The decision of David Cameron to agree to the televised debates was a game changer. David Cameron's first performance, like Gordon Brown's, was eclipsed by the dramatic effect of the performance of Nick Clegg. Liberal Democrat polling support surged and the attention thereafter to the Liberal Democrat leader was unprecedented for a third party. Overnight, the traditional campaign dominance of the Conservative and Labour leaders became a thing of the past, and the Conservative assumption that it was their campaign to win, or lose, was proved wrong. The fact that the extent of apparent Liberal Democrat support was not translated into votes should by no means detract from the profound significance of 'Cleggmania' on the 2010 campaign. The Conservative message was largely lost, and while David Cameron continued in his cross-country visits and campaigns, visiting factories and other venues to signal his commitment to economic recovery (as did Gordon Brown), and whereas campaign posters continued to warn of Labour's 'job tax' and attempts to make voters identify with 'new' Conservative voters, the story was Nick Clegg and the Liberal Democrats. The Conservatives launched a knee-jerk campaign, 
warning of the 'Hung Parliament Party'. They switched focus from Conservative-Liberal Democrat marginals and asked voters for a 'decisive' majority, but in the end they failed to provide a clear message.

What would the campaign have looked like without the leader debates? It is hard to say, but it appeared that the Conservatives had 'left their powder dry' on a series of policy announcements before the campaign and that the campaign would be characterised by issue-by-issue announcements of a range of new Conservative policies. This would have addressed the problem that voters were not sure what the Conservatives stood for and the 'Big Society' could have made the party look different to Labour, offering an inspirational narrative. That this was a risky strategy so late in the electoral cycle was certain before the campaign, but in the event, it was eclipsed by the three-horse race that the campaign was to become. In the BES Campaign Panel Internet Survey, the Conservatives began the campaign on April 6 with 39\% of electors intending to vote Conservative, but ended the campaign on May 5 with that figure at $36 \%{ }^{39}$ Once again, the Conservative campaign resulted in a decline in support.

As Denver shows in this volume, the Conservative party failed to achieve a breakthrough in Scotland. The Conservative party of 2010 was still predominantly the party of England and still far stronger in its electoral support in the South. David Cameron had stated the goal in his 2005 leadership speech, 'We've got to recognise that we're in third place among under-35s, that we've lost support among women, that public servants no longer think we're on their side, that the people with aspirations who swept Margaret Thatcher to power have drifted away from our party'. ${ }^{40}$ The Conservative goal under David Cameron was to reach out to those groups of voters.

The BES data shows that among under-35s the Conservatives moved from third to second place. In 2001, just $23.3 \%$ of under-35s reported a Conservative vote. This increased to $29.5 \%$ in 2010 , whereas the proportion voting Liberal Democrat was $38.4 \%$. The proportions of women expressing a Conservative vote saw little change, at $34.1 \%$ in 2005 and $35.2 \%$ in 2010 , but the Conservatives gained a lead over Labour, who secured $27.9 \%$ of women's reported votes (post-election BES, internet survey).

The following table provides the average change in Conservative vote, between 2005 and 2010, among areas of the country with the highest and lowest proportions of electors from various demographics; those aged between 18 and 24, those from upper middle and middle classes, lower middle and skilled working class categories (A and B, C1 and C2 groups, respectively) and areas with high and low proportions of ethnic minorities.

The data in Table 4 confirms the problem the Conservatives had among the youngest eligible voters, with only a modest increase in their vote between 2005 and 2010 in areas with high concentrations of 
4. Change in Conservative vote share, lower and upper quartile concentration by demographic, $2010 \mathrm{BBC}$ exit poll

Change in Conservative vote, 2005-2010

$\begin{array}{ll}\text { All areas (average) } & 3.8 \\ \% \text { 18-24 age group } & 3.9 \\ \text { Low } & 2.7 \\ \text { High } & 3.2 \\ \text { \% A and B social class } & 5.7 \\ \text { Low } & \\ \text { High } & 1.4 \\ \text { \% C1 social class } & 3.4 \\ \text { Low } & \\ \text { High } & 2.9 \\ \text { \% C2 social class } & 5.0 \\ \text { Low } & \\ \text { High } & 3.8 \\ \text { \%thnic minorities } & 2.5 \\ \text { Low } & \end{array}$

young voters. The table also reveals that the Conservative party suffered in areas with high concentrations of ethnic minorities. The evidence suggests that the Conservatives won support from C2 (skilled working class) voters, whilst also doing well in areas with the highest concentrations of $\mathrm{AB}$ voters. It appears that David Cameron succeeded in winning over the support of the 'people with aspirations' within the upper working class, also enjoying success among the upper middle and middle classes.

On a $36.1 \%$ share of the UK vote (36.9\% of the Great Britain vote), the Conservatives are now governing with a higher vote share than achieved by Tony Blair in 2005 (35.3\%), who won 356 seats in parliament. At a final result of 307 seats, however, a 'supply and confidence' arrangement with the Liberal Democrats, and other parties, was ultimately too unstable. This calculation was informed by the relatively weak mandate the party was given and the lack of a decisive electoral recovery.

\section{Conclusion}

David Cameron entered Number 10 Downing Street as Prime Minister on Wednesday 12 May 2010. He was the first Conservative opposition leader in 13 years to significantly increase the numbers of Conservative MPs and he was the first in that period to secure a consistent poll lead over Labour. He was undoubtedly more popular than recent Conservative opposition leaders before him, and his strategy of modernisation and of a new issue agenda must be attributed with some of this success.

However, this article has also highlighted the limits of the 'strategic recovery' which could be attributed to the Cameron strategy. Despite a 
period of modernisation, considerable work on policy, advances in campaigning, more money, a new more popular leader, a longer time period from which the memory of Conservative government could be a hindrance, and of course, the unpopularity of the Labour Prime Minister Gordon Brown and a serious recession, Conservative recovery has been partial. Although numbers of new voters were willing to cast a vote for the Conservatives, the Conservative base has not increased, and although the Conservatives were the most trusted party on important valence issues, the lead over Labour was narrow. For undecided voters, it was not clear that a Cameron government would be so much more desirable than the government they knew. The utility differential-the ranking difference of the Conservatives over Labour-was minimal on a range of criteria. A vote for the Conservatives in 2010 was largely instrumental: it was not cast with a growing sense of identification or of expressive support.

It is not possible to test the reasons for these successes, and failures, in the Conservative electoral recovery. Some successes may be due to David Cameron, others to his strategy, and had it not been for the expenses scandal, the opposition party's message might have gained more ground. However, it also the case that the Conservative lead over Labour coincided with the onset of the financial crisis, and that David Cameron's ratings improved at the same time. The narrowing gap between the two main parties on the crucial issue of the economy occurred as Britain emerged from recession. At least part of the explanation for the changes in Conservative fortunes is likely to be due to Labour's ratings on a range of competence criteria which suffered in 2008, and which began to improve at the beginning of 2010 . Therefore, we should be cautious in how much we credit electoral gains to the strategies of parties and leaders and cautious in assuming that a modest rise in Conservative vote represents a stable increase in Conservative electoral support. We should also look to the long-term nature of Conservative ratings before we attribute the lack of overall majority to the weakness of the short campaign.

Overall, there is a story of some electoral success, but the cost of government comes to all incumbents, and the Conservatives are not starting from the position they might have expected. The Conservative party entered government in an unenviable electoral position. It is difficult to predict the effects of coalition government on Conservative party support but it is likely to be a difficult period ahead. The necessary decision to enter a formal coalition with the Liberal Democrats can be seen in this context, and also in the context of the previous five years of Conservative opposition under David Cameron.

University of Manchester, Manchester, UK jane.green@manchester.ac.uk 
1 In the British Election Study pre-election in person survey (first beta release), $46 \%$ said they were still undecided who to vote for.

2 See B. Sárlvik and I. Crewe, Decade of Dealignment: The Conservative Victory of 1979 and Electoral Trends in the 1970s, Cambridge University Press, 1983; D. Granberg and S. Holmberg, The Political System Matters: Social Psychology and Voting Behaviour in Sweden and the United States, European Monographs in Social Psychology, Cambridge University Press, 1988.

3 G. Evans, 'Economics and Politics Revisited: Exploring the Decline in Conservative Support, 19921995', Political Studies, XLVII, 1999, 139-51.

4 Clause IV was the commitment in Labour's constitution to the common ownership of the means of production, which Tony Blair finally removed in 1994 in a symbolic expression of Labour's moderation and modernisation.

5 Sir Malcolm Rifkind and Alan Duncan both announced their intention to run, but withdrew before the ballot once it became clear they had insufficient support.

6 J. Petrocik, 'Issue Ownership in Presidential Elections, with a 1980 Case Study', American Journal of Political Science, 40, 1996, 825-50.

7 David Cameron 2005 Conservative Party Leadership Speech, accessed from http://www.guardian.co. uk/politics/2005/oct/04/conservatives2005.conservatives3.

8 P. Whiteley, J. Richardson and P. Seyd, True Blues: The Politics of Conservative Party Membership, Clarendon Press, 1994.

9 H. Clarke, D. Sanders, M. Stewart and P. Whiteley, Performance Politics and the British Voter, Cambridge University Press, 2009.

10 H. Clarke, D. Sanders, M. Stewart and P. Whiteley, Performance Politics and the British Voter, Cambridge University Press, 2009, Chapter 3.

11 D. Butler and D. Kavanagh, The British General Election of 2001, Palgrave, 2001.

12 There was one important mostly unseen change which built on the work done by Iain Duncan-Smith. The Conservative party adopted a far more social action oriented approach and philosophy in the years in opposition, with candidates and MPs getting involved in a broad range of hands-on projects, including projects overseas, as part of a commitment to international aid. The culture of the Conservative parliamentary party, in this respect, had certainly changed, and changed significantly.

13 David Cameron, This Sterile Fixation with Grammar Schools is a Dead End, Times 22 May 2007.

14 http://page.politicshome.com/uk/voters_expect_tory_government_to_raise_taxes.html.

15 P. Converse, 'The Concept of a Normal Vote', in A. Campbell, P. Converse, W. Miller and D. Stokes (eds), Elections and the Political Order, Wiley, 1966.

16 R. Johnston and C. Pattie, 'Representative Democracy and Electoral Geography', in J. Agnew, K. Mitchell, G. Thathail and G. Toal (eds), A Companion to Political Geography, Blackwell, 2003; G. Cox, Swing Voters, Core Voters and Distributive Politics. Paper presented at the Yale Conference on Representation and Popular Rule, 2006.

17 M. Fiorina, Retrospective Voting in American National Elections, Yale University Press, 1981.

18 See: Campbell, Angus, Philip E. Converse, Warren E. Miller and Donald E. Stokes, The American Voter, University of Chicago Press, 1976.

19 G. Evans, 'Economics and Politics Revisited: Exploring the Decline in Conservative Support, 19921995', Political Studies, XLVII, 1999, 139-51.

20 P. Cowley and J. Green, 'New Leaders, Same Problems: The Conservatives', in A. Geddes and J. Tonge (eds), Britain Decides: The UK General Election 2005, Palgrave Macmillan, 2005.

21 See D. Denver, Elections and Voters in Britain, Palgrave Macmillan, 2003.

22 D. Butler and D. Stokes, Political Change in Britain: Forces Shaping Electoral Choice, Macmillan, 1969.

23 The post-election average thermometer ratings, for the Conservative, Labour and Liberal Democrat parties were 4.5, 4.2 and 5.3, respectively (BES post-election internet survey), suggesting that the Conservatives were less liked following their 2010 campaign (those waves in which the question was asked. The 2010 pre-election BES was fielded before the leader debates).

24 P. Cowley and J. Green, 'New Leaders, Same Problems: The Conservatives', in A. Geddes and J. Tonge (eds), Britain Decides: The UK General Election 2005, Palgrave Macmillan, 2005. The satisfaction question is, 'Are you satisfied or dissatisfied with the way (David Cameron) is doing his job as Leader of the Opposition?'.

25 G. Evans and R. Andersen, 'Who Blairs Wins? Leadership and Voting in the 2001 General Election', British Elections and Parties Review, 13, 2003, 229-47.

26 As the election neared, Gordon Brown's net satisfaction-dissatisfaction score was -24 , but this was an improvement on a low of -51 in July 2008 and it was trending upwards from May 2009 (-43).

27 H. Clarke, D. Sanders, M. Stewart and P. Whiteley, Performance Politics and the British Voter, Cambridge University Press, 2009. 
28 J. Petrocik, 'Issue Ownership in Presidential Elections, with a 1980 Case Study', American Journal of Political Science, 40, 1996, 825-50.

29 See J. Green and S. Hobolt, 'Owning the Issue Agenda: Explaining Party Strategies in British General Election Campaigns', Electoral Studies, 27, 2008, 460-76.

30 Note that the proportion listing the Conservatives as the best party on the most important issue in the 2010 post-election British Election Study (internet) was $27.4 \%$ whereas for Labour the proportion was $21.7 \%$. The proportions for the Liberal Democrats and 'no party' were 11.7 and $27.1 \%$, respectively.

31 I. Budge and D. Farlie, Voting and Party Competition: A Theoretical Critique and Synthesis Applied to Surveys from Ten Democracies, Wiley, 1977.

32 See Ipsos-MORI data: http://www.ipsos-mori.com/researchspecialisms/socialresearch/specareas/ politics/trends.aspx.

33 This was motivated by two factors: first, to campaign on immigration risked positioning the Conservative party on the right—-the very problem David Cameron wanted to avoid. Second, the threat of a surge in British National Party support meant that all mainstream parties mostly avoided the issue.

34 A. Downs, An Economic Theory of Democracy, Harper \& Row, 1957.

35 D. Stokes, 'Spatial Models of Party Competition' The American Political Science Review 57, 1963, 368-77; J. Green, Jane, 'When Voters and Parties Agree: Valence Issues and Party Competition', Political Studies, 55, 2007, 629-55; H. Clarke, D. Sanders, M. Stewart and P. Whiteley, Performance Politics and the British Voter, Cambridge University Press, 2009.

36 J. Enelow and M. Hinich, The Spatial Theory of Voting: An Introduction, Cambridge University Press, 1984, in Hinich, m. Melvin J. and Michael C. Munger (eds), Analytical Politics, Cambridge University Press, 1997.

37 In a question in the British Election Studies, 23.4\% of survey respondents in 2005 agreed there was 'a great deal of difference between the main parties', whereas $84.6 \%$ agreed with the statement during Margaret Thatcher's leadership in 1987. These figures closely correspond with respondent placements of the two main parties on different policy scales.

38 The oft-cited quotation by Margaret Thatcher, argued to have been removed from context, Woman's Own, 23 September 1987.

39 Source: http://www.bes2009-10.org/.

40 David Cameron 2005 Conservative Party Leadership Speech, accessed from http://www.guardian.co. uk/politics/2005/oct/04/conservatives2005.conservatives3. 